\title{
ANALYZING SOCIAL ASPECTS IN THE SCARLET LETTER NOVEL BY NATHANIEL HAWTHORNE (A GENETIC STRUCTURALISM APPROACH)
}

\author{
Sulmi Magfirah
}

Universitas Fajar

Email:magfirahsulmi@yahoo.com

\begin{abstract}
Analyzing Social Aspects in the Scarlet Letter Novel by Nathaniel Hawthorne. This research aimed to find out how the structural element of the novel supported the whole idea of the story and the social aspects of Nathaniel Hawthorne novel "The Scarlet Letter". This thesis is library research and used descriptive method. The object of this research can be divided into two categories, namely primary and secondary data. The data were collected through several techniques, namely read the novel carefully, looked for the difficult word, taking note of the important parts both primary and secondary data, and then read some related literature to support the object that is analyzed. The result of this research show that the social aspects in the scarlet letter novel are divided into five categories, they are: (1) Family, (2) Religion, (3) Tradition, (4) Economy, (5) Education, and this thesis also described the structural elements that support the whole idea of the story.
\end{abstract}

Keywords: Social Aspect, Structural elements, Religion, Tradition

\begin{abstract}
Abstrak
Analisis sosial aspek yang terungkap dalam novel scarlet letter oleh Nathaniel Hawthorne. Penelitian ini bertujuan untuk menemukan struktur elemen yang terdapat dalam novel yang mendukung keseluruhan ide dalam cerita dan aspek social dalam novel "Scarlet Letter" oleh Nathaniel Hawthorne. Penelitian ini adalah bentuk penelitian pustaka dan menggunakan metode deskriptif. Objek penelitian ini terbagi menjadi dua kategori, yaitu data primer dan data sekunder. Data di kumpulkan melalui beberapa tehnik, seperti membaca novel dengan seksama, menemukan kata-kata sulit, mencatat bagian terpenting dari data penelitian, dan membaca beberapa referensi yang berkaitan untuk mendukung objek penelitian yang diteliti. Hasil penelitian ini menunjukkan bahwa aspek social yang terdapat dalam novel Scarlet Letter terdiri dari lima kategori, diantaranya; (1) Keluarga, (2) Agama, (3) Tradisi, (4) Ekonomi, (5) Pendidikan, dan penelitian ini juga menjelaskan struktur elemen yang mendukung semua ide dalam cerita. Kata Kunci: Aspek sosial, struktur elemen, Agama, tradisi
\end{abstract}

\section{INTRODUCTION}

Literature is one of the creations of human being. It is an art and can not be separated from human life. Literature is also an expression of thoughts and feelings through language as the medium. The creator of literature has been processing the objective fact by using imagination, so that it established mental imaginative fact.

Literary work offered to society as a description of social condition. It is created together with the author's view, aim, way of life, experience and even his emotion. Literary works also an experience of man about culture then human life, includes the 
whole aspects of human innate, affective, and expressed, such as sadness, kindness, truth, love and morality surrounds the action. Literary work is born in society as author's imagination and his reflection toward the social problems, therefore the existence of literature is a part of society life (Jabrohim, $2003: 59$ ).

Zeroffo in Mulawati (1973 : 53) stated that "the form and the content of the novel derive more closely from social phenomena than those arts, except perhaps cinema, novel often seems bound up with particular moment in the history of society. Novel can provide existing story and an escape from every day life, many novels encourage the reader to think about social, moral, conflict, philosophical problems. One novel that contains with life condition especially in social aspects life, it is "the scarlet letter" by Nathaniel Hawthorne.

Puritan's social conditions in the sixteenth century were colored by the witchraft phenomena made many suspicious to everybody who have different action, attitude and traits, they will give a predicate as the devil adherent, a witch to that people and the people have to expel from that city or executed by hanging and burning. From that phenomena, Nathaniel Hawthorne published a novel which arose many subjects of debate, opinion and comment from the readers and newspaper. The aspects of social life such as family, religion, tradition, economy, education and structural elements in was found in The Scarlet Letter novel.

Therefore, the writer of this paper used Genetic structuralism approach. It considered that the literary works as social product related to author's background and social reality at the time and situation currently. The data of the story, author's background, and social reality were collected by using library study and analyzed in descriptive method by using The Scarlet Letter by Nathaniel Hawthorne.

\section{Genetic Structuralism}

Goldman in Faruk (1999:12) called his theory as genetic structuralism. That is, he believes that literature is a structure. However, the structure is not something static, but rather is a product of an ongoing historical process, the structuration and destructuration that lived and internalized by the public from the relevant literature. According to Goldman in Faruk (1999: 12-20), to support his theory build a mutual set of categories related to one another to form what he called-genetic structuralism. The categories that are facts of humanity, the collective subject, structuration, world view, understanding and explanation. 
The fact of humanity is the result of human activity or behavior whether verbal or physical, which seeks to understand science. facts that can be either a specific social activity, certain political activities, as well as cultural creations such as philosophy, art, music, sculpture, literature and art. Humanitarian facts that can essentially be divided into two kinds, namely the individual facts and social facts. Goldman in Faruk (1999: 13) assumed that all the facts of humanity is a meaningful structure. He meant was that the facts as well have a particular structure and particular meaning. Therefore, an understanding of the facts of humanity has to consider the structure and meaning

Goldman believes in the existence of homology between the structures of literary works to the structure of society because they are the product of the same structuration activity. However, the relationship between community structures with the structure of literary works is not understood as a relation of determination is direct, but mediated by what it called a worldview or ideology.

Goldman expressed two opinions about literature in general, the first that the literary work is an expression of views in an imaginary world. The second is that in attempting to express the world view that the author created the universe figures, objects, and relations are imaginary. Thematic nature of concept Goldman structure was seen also in the concept of the novel, with regard to the importance of genetic structuralism approach, Goldman deems examine two things that concerned each other: the way of researching the novel (read: literary text) itself and its relationship with socio-cultural. The study of genetic structuralism sees literature from two angles namely intrinsic and extrinsic. This approach has aspects that are useful and highly efficient, if the researchers themselves did not forget or permanent concern with the building intrinsic literature. In addition to attention the sociological factors, and fully aware that literary works were created by some creativity by making use of the imagination factor.

Historical background, times and society affect the process of creating literary works. The existence of the authors in a certain society also influences. Thus, one certain society that supports authors may automatically produce a literary work. The author as individual subject tries to create his world vision to his collective subject. Definitely, genetic structuralism is the structure analysis by giving attention to the origin of literary work, its mean that genetic structuralism give attention to intrinsic and extrinsic elements of a literary work (Ratna, 2004: 123).

The work of genetic structuralism research can be formulated in three steps; first, the researcher will analyze intrinsic aspect, either in partial or in whole intrinsic aspects of a literary work. Second, researcher will analyze the social culter's author, because he is a part of certain community. And the last, the researcher will analyze social and historical background which influence the literary work when it created by author. 


\section{RESEARCH METHODOLOGY Source of Data}

The data used by the researcher in this research were taken from Nathaniel Hawthorne's The Scarlet Letter as the primary data and the secondary data were taken from various books, articles, Britannica and website on internet. Through this secondary data, the researcher collects and used them as they are relevant to the topic.

\section{Method of Collecting Data}

The researcher read the text of the novel by close reading and tries to catch the ideas related to the problem investigated. Such data are in the form of texts, sentences, phrase, word, description, which show the social aspects when the novel was written. By collecting the data, the researcher does not only use library research, but also noting after reading, finds out the data through internet.

\section{Method of Analyzing Data}

In this research, the researcher uses method of data analysis to support the analysis. In analyzing this novel, the researcher uses descriptive method, Genetic Structuralism approach by Lucian Goldman theory which focus on the social aspects in the novel. The researcher does close reading of the novel, determines the main focus on the research and highlights some important quotations from the novel to support the analysis.

\section{Procedure of Collecting Data}

In this research, the researcher does some procedures, such as read the novel carefully, intensively and writes the important note on the left side of the important quotation. Next, identifying some cases containing social aspects in the novel. Then, read the novel and correlated with the supporting data from other sources and use Genetic Structuralism approach. Finally, conclude the result of the research.

\section{FINDINGS}

\section{A. Analysis of Structural Elements of Novel}

Based on the theory (Genetic Structuralism), the first step done by the writer in this research is to analyze the intrinsic elements (structure). These elements will point out the evidences which are integrated in the novel. So, the researcher could delineate some social aspects in the novel. The structural elements here mention about the elements that building up the story, especially intrinsic elements such as theme, setting, character and characterization, and symbol.

For the major character, there are four characters that most influence of the story, the characters are: Hester Prynne as one of important characters was found in adultery. Otherwise, she also had to stand on the pillory holding her illegitimate child for several hours and she condemned wears the scarlet letter ' $A$ ' forever in her life. Arthur Dimmesdale, he was a true priest and fanatics to learn about a true religionist. 
But Arthur's attitude is bad history in Boston, however the puritan society still respect with the young clergyman when he was toward his mortally. Roger Chillingworth here plays a main antagonist. his full of ambition and anger cause just to look his wife's (Hester) betrayal and disgrace. Pearl, she is an illegitimate daughter, she is very beautiful and has inner beauty.

The setting of this novel is in the puritans had settled in New England, Puritan communities were centered on the idea of purity in thought and deed, and sins were rooted out and punished harshly. The Scarlet Letter "A" is meant to be a symbol of shame, but instead of it becomes a powerful symbol of Hester's identity. The "A" eventually comes to stand for "Able". Pearl, her primary function within the novel as a symbol. She is the physical consequence of sexual sin and the indicator of a transgression. Pearl's existence gives her mother reason to life and bolstering hester's spirits.

\section{B. Analysis of Social Aspects in Nathaniel Hawthorne Novel 'The Scarlet Letter'}

The Scarlet Letter tells about the story of women's shame and cruel treatment she suffers at the hands of puritan's society in which she lives. A young woman, Hester Prynne, is led from the town prison with her infant daughter, Pearl in her arms and the scarlet letter "A" on her chest, it is to be a symbol of her sin a badge of shame for all to see. Based on the scope of the research, this section will focuse on the social aspects of the novel which are divided into five basic futures, there are family, religion, tradition, economy and education. There are:

\section{- Family}

Hawthorne explains the family in American culture through the scarlet letter novel, relationship between Hester Prynne (Wife) and Roger Chillingworth (Husband), then the relationship among Hester Prynne, Arthur Dimmesdale and Peral (Daughter). Before Hester get the symbol of scarlet letter and move to Boston, she has a husband, his name is Roger and because he is very busy, so that he send out his wife to go first to Boston, but they meet again with different and difficult situation in foreign region. Because of Hester's sinning, he feels treasonable as a husband. So that, he makes a decision about their relationship, which is hide their marital status, let everyone know your husband was died and don't let the society know about his identity. 
Hester Prynne commits adultery with Arthur Dimmasdale and together they have a child named Pearl. Hester refuses to betray her lover, but realizes from her perspective on the scaffold that she must faces her trials alone, that neither of the men who has affected her life will openly be a part of her future. Hester loves her daughter, carries on the back, care, and makes Pearl a good child. So that, they were very committed each other like only two people in the world.

\section{- Religion}

Hester and Dimmesdale's worst attitude has resulted expulsion and suffering. the scarlet letter's function as her passport into regions where other women dared not tread, leading her to speculate the society and herself more boldly than anyone else in New England. Because of her sin, she was wearing the scarlet letter " $A$ " in front of puritanical during one hour in the afternoon. The Puritan society never know her couple, who is she together with, except her daughter. Hester felt isolated and suppressed from puritan society because of her bad attitude. All of people scornful her, however they were unsatisfied and they want saw her death. a judgment of puritans' society "Thus she will be a living sermon against sin, until the ignominious letter be engraved upon her tombstone" (Hawthorne, 1850: 63).

\section{- Tradition}

The puritan society was still related with theirstom or have tradition. created many extreme constitutions and laws that was controlled the social system of puritan society in Boston New England. One of them was restriction of polygamy and painful punishment to the adulterer. Hester was arrested to stand in the front of society with the scarlet letter, and she must wear the symbol until died. Puritan society will give painful punishment to the adulterer by standing for several hours on the pillory in front of them or the convicts have to whip and always wear the symbol. Everyday Hester will face the humiliation to society. Hester's attitude becomes tradition in the puritan society, they were young, holy and children from wellborn will be preached by the symbol of the scarlet letter. 


\section{- Economy}

Hester who wished to still continue her better life for future and try to looked for a way to defendable in Boston, although many people did not like her, but there are like her embroidery. Hester wants to change her image and change people's perception of her, not to look her scarlet letter but her kindness and competences. The humiliation where she gets in her everyday life make her to be strong woman., Hester has changed little model of the puritan clothes and made it more interests than before, such as gauntly, shawl and ceremonial vestment, so that many puritan people used her embroidery. puritan society had not been quite care Hester's status, because of her skill and kindness. Besides that, from the income of her embroidery, she prefers to choose charitable who was more suffered than her. Hester's skill helps and satisfy her and Pearl material need.

\section{- Education}

Arthur was person who has high education of religion. He always shares knowledge to the puritan society. Because in Boston was wild land and less of education. The young clergyman's voice was sweet, rich, deep and broken. So evidently manifested, rather than the direct purports of the words, caused vibrate within all hearts, and brought the listeners into sympathy.

Besides that, one person also has good education is Roger Chillingworth. He was an intelligence and more than a common measure, a doctor and he was made extensively acquainted with the medical science also cure of diseases. In Boston, someone who has physical knowledge will be received well because of medical can restorative of diseases. Based on his background, he kept the young clergyman when he was sick, not only the clergyman, but also Hester and her baby when they were in prison. As a professional physical, although she is Roger's ex wife, enemy, but he must treat as the obligation of physician without differentiate the patient.

\section{CONCLUSION}

Based on the analysis in the previous chapter, the researcher concludes that; The structural elements that support the whole idea of the story are theme, character and characterization, setting and symbol. They are influence each other, and get more important information of the story. While, the social aspects of Nathaniel Hawthorne novel "the scarlet letter" are family, religion, tradition, economy, and education. The five aspects are very eminent, related and influence the content of the story. 


\section{REFERENCES}

Ali, Muhammad. 1986. Ihwal Dunia Sastra. Surabaya: PT. Bina Ilmu.

Aminuddin. 2009. Pengantar Apresiasi Karya Sastra. Bandung: Sinar Baru Algensindo.

Endraswara, Suwardi.2008. Metode Penelitian Sastra. Yogyakarta: MedPress.

Faruk. 1999. Pengantar Sosiologi Sastra. Yogyakarta: Pustaka Pelajar.

Goldmann, Lucient. 1977. Towards Sociology of the Novel. London. Tavistoct Publications Ltd.

Halim, Abdul.2007. English Prose. Makassar: State University of Makassar.

Hawthorne, Nathaniel. 1850. The Scarlet Letter. Salem: Cardinal Edition.

Iskandar. 2005. Introduction to literature; State University of Makassar.

Macionis, John J. 1993. Sociology Fourth Edition. New Jersey. Prentice Hall

Nurgiyantoro, Burhan. 1994. Teori Pengkajian Fiksi. Yogyakarta: gadjah Mada University Press.

Park, E Robert and Burgess W Ernest. 1970. Introduction to the Science of Sociology. America: University of Chicago.

Ratna, Nyoman Kutha.2009. Teori, Metode, dan Teknik Penelitian Sastra. Yogyakarta: Pustaka Pelajar. 